2009-05

\title{
Cauda equina syndrome following a lumbar puncture
}

\author{
Sinclair, AJ
}

http://hdl.handle.net/10026.1/3490

10.1016/j.jocn.2008.07.079

Journal of Clinical Neuroscience

Elsevier BV

All content in PEARL is protected by copyright law. Author manuscripts are made available in accordance with publisher policies. Please cite only the published version using the details provided on the item record or document. In the absence of an open licence (e.g. Creative Commons), permissions for further reuse of content should be sought from the publisher or author. 


\title{
Cauda equina syndrome following a lumbar puncture
}

\author{
Alexandra J. Sinclair ${ }^{\mathrm{a}, \mathrm{b}, \mathrm{c}, *}$, Camille Carroll ${ }^{\mathrm{a}}$, Brendan Davies ${ }^{\mathrm{b}}$ \\ ${ }^{a}$ Department of Neurology, Queen Elizabeth Hospital, University Hospital Birmingham NHS Trust, Birmingham, England, UK \\ ${ }^{\mathrm{b}}$ University Hospital of North Staffordshire, Stoke-on-Trent, England, UK \\ 'School of Immunology, Infection and Inflammation, College of Medical and Dental Sciences, University of Birmingham, Birmingham, England, UK
}

\section{A R T I C L E I N F O}

\section{Article history:}

Received 21 April 2008

Accepted 3 July 2008

\section{Keywords:}

Cauda equina syndrome

Lumbar puncture

Spinal haematoma

\begin{abstract}
A B S T R A C T
Lumbar puncture (LP), a common diagnostic procedure, is usually associated with low morbidity. We describe the case of a 29-year-old woman who underwent a non-traumatic LP in the setting of normal coagulation. Cauda equina syndrome subsequently developed secondary to an extradural spinal haematoma. Avoidance, identification and management of this uncommon complication are discussed.

Iatrogenic cauda equina syndrome following LP is rare, but can cause significant morbidity. Our patient's experience and our review of the literature highlight that: (i) normal coagulation and a nontraumatic LP do not exclude this diagnostic possibility; (ii) early recognition determines the management and prognosis, as 50\% of patients remain paraplegic if the condition is identified more than 12 hours after symptom onset; and (iii) neurosurgical intervention can be avoided, despite bladder dysfunction, if there are early signs of recovery.
\end{abstract}

(c) 2008 Elsevier Ltd. All rights reserved.

\section{Introduction}

Lumbar puncture (LP) is a common diagnostic procedure that is relatively straightforward to perform and usually associated with low morbidity. Though rare, significant neurological complications can occur. We present a case of extradural spinal haematoma (EDH) following LP. Early recognition of this disabling condition is important to reduce morbidity.

\section{Case report}

A 29-year-old woman underwent a LP for suspected demyelinating disease. Fully informed, written consent was obtained prior to the procedure. The LP was non-traumatic ( 2 red blood cells per $\mu \mathrm{L}$ of cerebrospinal fluid [CSF]), and the patient was asymptomatic following the procedure. Eight hours post-procedure the patient complained of progressive lower back pain, numbness of the sole of her right foot and weakness in her right leg. Examination of the right leg revealed a right L5/S1 neuropraxia (weakness in gluteus maximus [Medical Research Council (MRC) grade 4/5], tibialis anterior [MRC grade 0/5] and the hamstrings [MRC grade 4/5], absent right ankle reflex and S1 sensory loss). The bladder was also distended. An MRI identified a lentiform mass posterior to the $L 4 / 5$ vertebral bodies compressing the cauda equina nerve roots. No vascular anomaly was seen. The imaging findings were consistent with an EDH (Fig. 1). Further laboratory investigations revealed normal coagulation.

Sensory recovery was documented over the subsequent hours, and following neurosurgical consultation the haematoma was managed conservatively with dexamethasone $(4 \mathrm{mg}$ four times per day for 48 hours). Examination at discharge, 3 weeks later, revealed mild weakness in the tibialis anterior $\left(4^{+} / 5\right)$. A full recovery was noted at 3 months.

\section{Discussion}

Cauda equina syndrome secondary to EDH is a rare and potentially devastating complication of LP that can result in permanent

\footnotetext{
* Corresponding author. Tel.: +44 121414 2764; fax: +44 1214158712

E-mail address: a.b.sinclair@bham.ac.uk (A.J. Sinclair).
}

paraparesis and loss of sphincter control. We discuss avoidance, identification and management.

Primary prevention should ensure LPs are only performed when truly justified, and then only after fully informed, written consent (including an explanation of the potential risk of bleeding). ${ }^{1}$ Clotting abnormalities should be corrected preprocedure; spinal haematoma following LP is associated with coagulopathy in 47\% of patients (Table 1). A midline LP approach will minimise the risk of trauma to the artery and vein of Adamkiewicz, which are implicated in spinal bleeding. The impact of the spinal needle diameter and type are not established.

Following LP, the principle indicator of spinal haematoma is severe lower back or radicular pain, found in approximately $58 \%$ of patients (Table 1). Additionally, symptoms of cauda equina compression and meningism are typical. Our review of the literature (Table 1$)$ identified that time to presentation is variable: acute, less than 6 hours ( 4 out of 18 cases, 22\%), subacute, 6 to 24 hours (11 out of 18 cases, $61 \%$ ), and chronic, greater than 24 hours ( 3 out of 18 cases, $17 \%$ ). An absence of red blood cells in the CSF does not preclude the diagnosis; $50 \%$ of reported cases document clear spinal fluid (Table 1). Physician awareness of spinal haematoma following LP is vital to expedite neurological examination and subsequent MRI scanning. ${ }^{2}$ Delayed diagnosis is associated with poor prognosis. ${ }^{3-5}$ We note that $70 \%$ of instances are identified after 12 hours and, of these, 50\% remain paraplegic and disabled. Overall, $37 \%$ of patients with spinal haematoma remain paraplegic (Table 1).

Management of post-LP spinal haematoma is similar to that of haematoma resulting from other causes. Clotting anomalies should initially be corrected. Rigorous clinical research to support surgical intervention versus conservative treatment is lacking. ${ }^{3,6-9}$ Our review highlights that patients with $\mathrm{EDH}$ are equally likely to receive surgical intervention or conservative treatment, while those with subdural haematoma are more likely to be treated only surgically (67\%). Additionally, conservative treatment may be appropriate in those patients who have mild symptoms and early signs of recovery. ${ }^{9}$ In these instances, dexamethasone treatment and prolonged vigilant monitoring are advised. The most important prognostic factors, however, are time from LP to diagnosis, time from diagnosis to intervention, ${ }^{5}$ and the extent of paraplegia at presentation. $^{3}$ 
Table 1

Reported instances of spinal haematoma following a lumbar puncture

\begin{tabular}{|c|c|c|c|c|c|c|c|c|c|}
\hline Case & Article & Procedure & $\begin{array}{l}\text { Clotting } \\
\text { defect }\end{array}$ & $\begin{array}{l}\text { Time to } \\
\text { presentation }(\mathrm{h})\end{array}$ & Pain & $\begin{array}{l}\text { Red cell count in } \\
\operatorname{CSF}(\mu \mathrm{L})\end{array}$ & Haematoma & $\begin{array}{l}\text { Management (time post- } \\
\text { procedure) }\end{array}$ & Outcome \\
\hline 1 & Edelson et al., $1974{\text { Arch } \text { Neurol }^{10}}^{10}$ & LP & Yes & 2 & Nil & 0 & SDH & Conservative & Severe paraplegia \\
\hline 2 & Edelson et al., 1974 Arch Neurol $^{10}$ & LP & Yes & 12 & Nil & 1250 & Lumbar & Conservative & Mild sensory disturbance \\
\hline 3 & Edelson et al., 1974 Arch Neurol $^{10}$ & LP & Yes & 1 & Nil & 0 & SDH & Conservative & Severe paraplegia \\
\hline 4 & $\begin{array}{l}\text { Rengachary and Murphy, } 1974 \mathrm{~J} \\
\text { Neurosurg } 11\end{array}$ & $\begin{array}{l}\text { Spinal } \\
\text { anaesthesia }\end{array}$ & No & 12 & Nil & Unknown & SDH & Surgical $(>12 \mathrm{~h})$ & Mild paraparesis \\
\hline 5 & $\begin{array}{l}\text { Kirkpatrick and Goodman, } 1975 \text { Surg } \\
\text { Neurol }^{12}\end{array}$ & Myelography & No & 24 & Lower back & Clear CSF & SAH & Surgical ( 5 days) & Mild paraparesis \\
\hline 6 & Gutterman, 1977 Surg Neurol ${ }^{13}$ & LP & No & $12-20$ & Lower back & Blood-stained CSF & SDH & Surgical $(30 \mathrm{~h})$ & $\begin{array}{l}\text { Moderate right leg } \\
\text { weakness }\end{array}$ \\
\hline 7 & Diaz et al., 1978 Neurosurgery ${ }^{14}$ & LP & No & 18 & Nil & 228 & EDH & Surgical & Full recovery \\
\hline 8 & Dean and Woodside, 1979 Urology 6 & LP & Yes & 24 & Nil & 0 & SDH & Conservative & Death from unrelated cause \\
\hline 9 & $\begin{array}{l}\text { Guthikonda et al., } 1979 \\
\text { Neurosurgery }^{15}\end{array}$ & LP & Yes & - & Unknown & Unknown & SDH & Surgical & Unknown \\
\hline 10 & Blade et al., $1983 \mathrm{~J} \mathrm{Neurosurg}^{16}$ & LP & Yes & 10 & Back & Clear CSF & SAH & Surgical (48 h) & Mild paraparesis \\
\hline 11 & Owens et al., 1986 Anesth Analg ${ }^{17}$ & $\begin{array}{l}\text { Epidural } \\
\text { anaesthesia }\end{array}$ & Yes & 16 & Severe back & 1450 & SDH & Surgical (22 h) & $\begin{array}{l}\text { No recovery from } \\
\text { paraparesis }\end{array}$ \\
\hline 12 & $\begin{array}{l}\text { Spanu et al., } 1988 \text { Neurochirurgia } \\
\text { (Stuttg) }^{18}\end{array}$ & LP & No & - & $\begin{array}{l}\text { Severe back } \\
\text { and leg }\end{array}$ & 0 & SDH & Surgical & Full recovery \\
\hline 13 & Bills et al., 1991 Aust N Z J Surg ${ }^{3}$ & $\begin{array}{l}\text { Epidural } \\
\text { anaesthesia }\end{array}$ & Yes & 48 & Back & Unknown & SDH & Surgical $(<24 \mathrm{~h})$ & $\begin{array}{l}\text { No recovery from } \\
\text { paraparesis }\end{array}$ \\
\hline 14 & $\begin{array}{l}\text { Metzger and Singbartl, } 1991 \text { Acta } \\
\text { Anaesthesiol Scand }{ }^{4}\end{array}$ & $\begin{array}{l}\text { Epidural } \\
\text { anaesthesia }\end{array}$ & Yes & 12 & Nil & Unknown & EDH & Surgical (3 days) & Severe paraplegia \\
\hline 15 & $\begin{array}{l}\text { Boukobza et al., } 1994 \\
\text { Neuroradiology }\end{array}$ & $\begin{array}{l}\text { Epidural } \\
\text { anaesthesia }\end{array}$ & No & - & Unknown & Dry tap & EDH & Conservative & Mild paraparesis \\
\hline 16 & Peltola et al., 1996 Lancet $^{19}$ & LP & No & $<1$ & $\begin{array}{l}\text { Severe back } \\
\text { and leg }\end{array}$ & Clear CSF & EDH & Surgical & Mild sensory disturbance \\
\hline 17 & Egede et al., 1999 Md Med J ${ }^{20}$ & LP (traumatic) & No & 72 & Back and neck & 1425 & SDH & Conservative & Full recovery \\
\hline 18 & Wirtz et al., 2000 Pediatr Neurol $^{21}$ & LP & Yes & 24 & Back & 15 & SDH & Surgical (3 days) & Mild paraparesis \\
\hline 19 & $\begin{array}{l}\text { Adler et al., } 2001 \text { Pediatr Emerg } \\
\text { Care }^{22}\end{array}$ & LP & No & 4 & $\begin{array}{l}\text { Severe back } \\
\text { and leg }\end{array}$ & 63 & EDH & Conservative & Full recovery \\
\hline 20 & Chan and Bailin, $2004 \mathrm{~J}$ Clin Anesth ${ }^{5}$ & $\begin{array}{l}\text { Spinal } \\
\text { anaesthesia }\end{array}$ & No & 72 & $\begin{array}{l}\text { Mild lower } \\
\text { back }\end{array}$ & Blood-stained CSF & EDH & Conservative & $\begin{array}{l}\text { No recovery from } \\
\text { paraparesis until death }\end{array}$ \\
\hline 21 & Tubbs et al., 2004 Pediatrics $^{23}$ & LP & No & $\sim 12$ & Nil & Clear CSF & SDH & Surgical & Severe paraplegia \\
\hline
\end{tabular}

$\mathrm{CSF}=$ cerebrospinal fluid, $\mathrm{EDH}=$ extradural haematoma, $\mathrm{h}=$ hours, $\mathrm{LP}=$ lumbar puncture, $\mathrm{SAH}=$ subarachnoid haematoma, $\mathrm{SDH}=$ subdural haematoma 

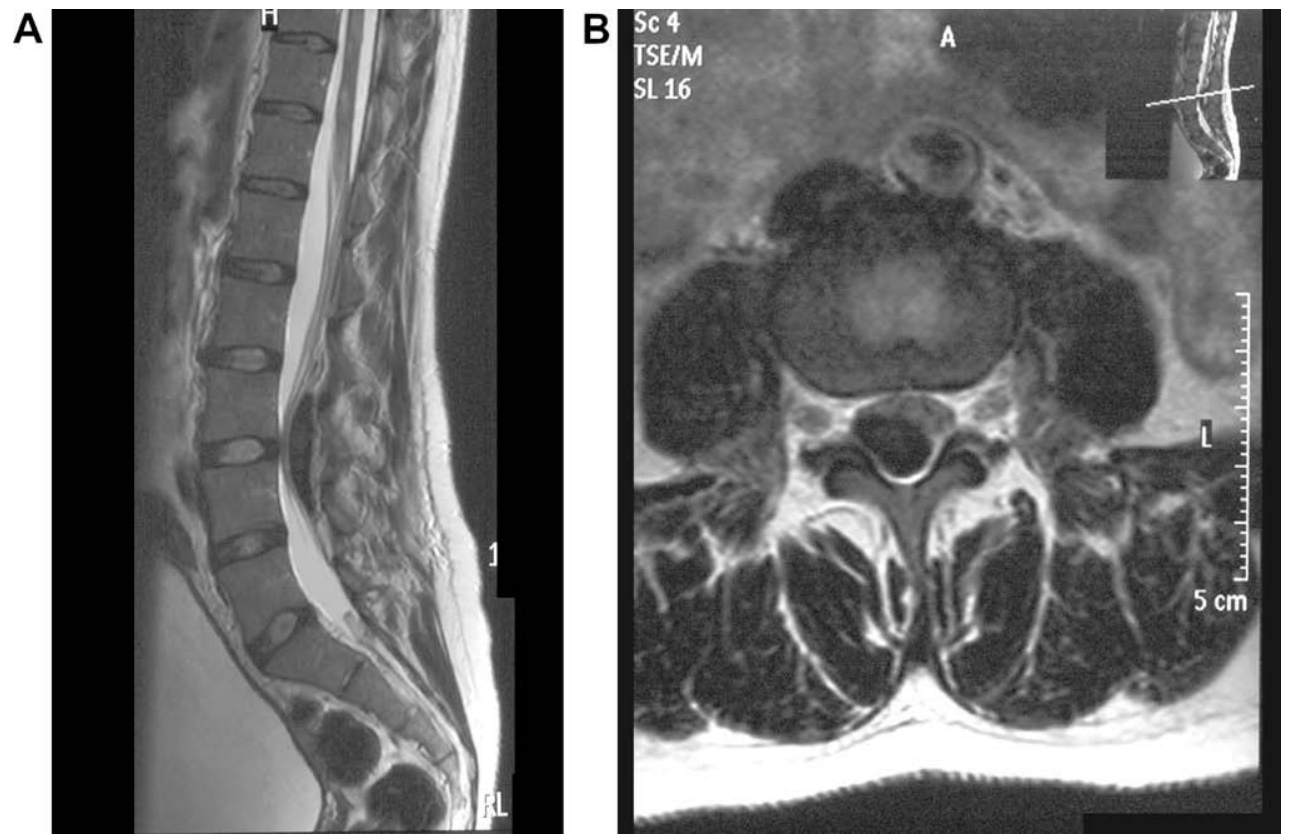

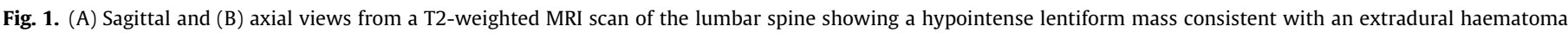
impinging on the cauda equina.

\section{Conclusion}

The rare complication of spinal haematoma following LP can result in significant morbidity, particularly if the diagnosis is delayed; $50 \%$ of patients remain paraplegic if spinal haematoma is identified more than 12 hours after symptom onset. Normal coagulation and a non-traumatic LP do not exclude this diagnostic possibility. Even with bladder dysfunction, neurosurgical intervention is not always necessary if there are early signs of recovery.

\section{References}

1. Beresford HR. Informed consent before lumbar puncture. $N$ Engl J Med 1980;303:1534.

2. Sklar EM, Post JM, Falcone S. MRI of acute spinal epidural haematomas. $J$ Comput Assist Tomogr 1999;23:238-43.

3. Bills D, Blumbergs P, North J. Iatrogenic spinal subdural haematoma. Aust NZ J Surg 1991;61:703-6.

4. Metzger G, Singbartl G. Spinal epidural hematoma following epidural anaesthesia versus spontaneous spinal subdural hematoma. Two case reports. Acta Anaesthesiol Scand 1991;35:105-7.

5. Chan L, Bailin M. Spinal epidural hematoma following central neuraxial blockade and subcutaneous enoxaparin: a case report. J Clin Anesthesia 2004;16:382-5.

6. Dean W, Woodside J. Spinal hematoma compressing cauda equina. Urology 1979;13:575-7.

7. Kong J, Mak K. Spontaneous spinal epidural haematoma - an unusual cause of spinal cord compression. Hong Kong Med J 2003;9:55-7.

8. Khaled K, Awad J. Spinal epidural hematoma causing acute cauda equina syndrome. Neurosurg Focus 2004;16:1-4.

9. Boukobza M, Guichard J, Boissonet M, et al. Spinal epidural haematoma: report of 11 cases and review of the literature. Neuroradiology 1994;36:456-9.
10. Edelson RN, Chernik NL, Posner JB. Spinal subdural hematomas complicating lumbar puncture. Arch Neurol 1974;31:134-7.

11. Rengachary SS, Murphy D. Subarachnoid hematoma following lumbar puncture causing compression of the cauda equina. Case report. J Neurosurg 1974;41:252-4.

12. Kirkpatrick D, Goodman SJ. Combined subarachnoid and subdural spinal hematoma following spinal puncture. Surg Neurol 1975;3:109-11.

13. Gutterman P. Acute spinal subdural hematoma following lumbar puncture Surg Neurol 1977;7:355-6.

14. Diaz FG, Yock Jr DH, Rockswold GL. Spinal subarachnoid hematoma after lumbar puncture producing acute thoracic myelopathy: case report Neurosurgery 1978;3:404-6.

15. Guthikonda M, Schmidek HH, Wallman LJ, et al. Spinal subdural hematoma: case report and review of the literature. Neurosurgery 1979;5:614-6.

16. Blade J, Gaston F, Montserrat E, et al. Spinal subarachnoid hematoma after lumbar puncture causing reversible paraplegia in acute leukemia. Case report. $J$ Neurosurg 1983;58:438-9.

17. Owens EL, Kasten GW, Hessel 2nd EA. Spinal subarachnoid hematoma after lumbar puncture and heparinization: a case report, review of the literature, and discussion of anesthetic implications. Anesth Analg 1986;65:1201-7.

18. Spanu G, Berlanda P, Rodriguez y, et al. Spinal subdural haematoma: a rare complication of lumbar puncture. Case report and review of the literature. Neurochirurgia (Stuttg) 1988;31:157-9.

19. Peltola J, Sumelahti ML, Kumpulainen T, et al. Spinal epidural haematoma complicating diagnostic lumbar puncture. Lancet 1996;347:131.

20. Egede LE, Moses H, Wang H. Spinal subdural hematoma: a rare complication of lumbar puncture. Case report and review of the literature. Md Med J 1999;48:15-7.

21. Wirtz PW, Bloem BR, van der Meer FJ, et al. Paraparesis after lumbar puncture in a male with leukemia. Pediatr Neurol 2000;23:67-8.

22. Adler MD, Comi AE, Walker AR. Acute hemorrhagic complication of diagnostic lumbar puncture. Pediatr Emerg Care 2001;17:184-8.

23. Tubbs RS, Smyth MD, Wellons 3rd JC, et al. Intramedullary hemorrhage in a neonate after lumbar puncture resulting in paraplegia: a case report. Pediatrics 2004;113:1403-5. 